\title{
Dislocation and Uncertainty in East Manchester: The Legacy of the Commonwealth Games
}

\section{by Camilla Lewis \\ University of Manchester}

Sociological Research Online, 20 (2), 13 $<\mathrm{http}: / /$ www.socresonline.org.uk/20/2/13.html> DOI: $10.5153 /$ sro. 3607

Received: 15 Sep 2014 | Accepted: 30 Jan 2015 | Published: 31 May 2015

\begin{abstract}
In 2002, the Commonwealth Games were championed as a win-win solution for Manchester. The sporting event would bring worldwide attention and investment to the city and offer a unique opportunity to kick start social regeneration, transforming the fortunes of some of Manchester's poorest neighbourhoods. This paper explores experiences of urban change, from the perspective of long-standing residents in the neighbourhoods of Beswick and Openshaw, which lie in East Manchester. Despite promises of legacy, these localities residents in the neighbourhoods or Boswick and Openshaw, which lie in East Manchester. Desplte promises ol legacy, hese localles remain dislocated from the rest of the city and the future continues to be defined by uncertainty by the area's residents. In order to understand some of the tensions and difficulties that arise in projects of urban transformation we need to pay attention to the practical ways in which people make relationships to place (Massey 1995, 2001) which tend to be erased in dominant narratives about 'legacy'. II argues that we must go beyond drawing simple conclusions of the 'positive' or 'negative' implications of regeneration processes in order
\end{abstract} to investigate the social effects of urban change for local populations.

Keywords: Commonwealth Games, Urban Regeneration, Community, Legacy, Place, Social Change

\section{Introduction}

In 2002, the Commonwealth Games were championed as a win-win solution for Manchester. The sporting event would bring worldwide attention and investment to the city and offer a unique opportunity to kick start social regeneration, transforming the fortunes of some of Manchester's poorest neighbourhoods. The Games were the first major sporting event which involved a strategic framework for the regeneration of the city (Gratton et al. 2005). The Legacy Programme was introduced to ensure that the event was 'more than ten days of sport' and to guarantee that disadvantaged communities throughout the North West of England would benefit from Manchester hosting the event. ${ }^{[1]}$ New East Manchester, the urban regeneration company which was established to manage the work, described how the project was 'one of the largest, most challenging and exciting renaissance initiatives in the UK'[2].

Regeneration, of the type seen in East Manchester, has faced widespread opposition due to its support of entrepreneurial forms of urbanism. According to critical urban scholars, 'new urban politics' is based on an economic approach in which the city was viewed by the government and developers as a business (MacLeod \& Ward 2002; Ward 2003). The consequences for deprived neighbourhoods, according to Raco R003) have been deeply damaging as regeneration efforts have not generated significant benefits for the communities residing in them. This is because, under the entrepreneurial model, the reorganisation of the city has produced unequal social, economic, cultural and, political effects (Harvey 1989). This paper makes an intervention into these debates by examining the legacy of the Commonwealth Games for long-standing residents in the neighbourhoods of East Manchester ten years after the event took place. My ethnographic findings reveal that despite the promises of legacy, East Manchester remains dislocated from the rest of the city and the future continues to be defined by uncertainty. I argue that even though the entrepreneurial critiques highlight the uneven economic effects of redevelopment, they need to be extended further, so they give voice to the opinions of local residents and therefore, draw attention to the deep sense of unease which is evident in these localities. In order to do so, a nuanced understanding of place making is required which takes account of the plurality of perspectives of people living in these localities and their experiences of the changes which have been brought about after the Games.

The paper unfolds as follows. First, I present a brief history of East Manchester and explain how this locality was chosen to host the Commonwealth Games. Second, I present the results of my ethnographic research about how local residents perceive East Manchester and the legacy of the Games and explain how notions of place are highly contested in the regenerated landscape. Third, I argue that the persistent feelings of uncertainty and confusion in East Manchester which I observed cannot be explained simply by critiques of entrepreneurial urbanism (Mellor 2002; Cook \& Ward 2011; Ward 2003) but require a more nuanced approach to place making. Following Massey $(1995,2001)$, I suggest that there is no uniform response to the change in the landscape but, for residents in East Manchester, layers of meaning are embedded into their accounts of the built space. To conclude, I argue that in order to further sociological understandings of legacy, it is necessary to shed light on ambiguous lived responses to change and therefore examine how place-making occurs in regenerated localities, rather than thinking about legacy as something measurable which can be conceived of in 'positive' or 'negative' terms.

\section{Sporting Legacies}

In an interview reported in the Manchester Evening News, Sir Richard Leese, the leader of Manchester City Council since 1996, described the Commonwealth Games as a 'catalyst for change' which would bring about a lasting legacy for communities. [3] He argued that the Games placed Manchester on the 'world stage, as a renowned destination for the arts, culture, sports and business'. For Leese and other city planners and politicians, sporting events are seen as a means of inviting urban economic development and transformation. Unique opportunities like the Games have been viewed as a way of encouraging private investment, tourism, jobs and other economic investments in cities (Cook \& Ward 2011; MacRury 2008). It was hoped that they would also stimulate social regeneration. For Leese, the investment which was made in the Games has paid off. He argues that the sporting infrastructure has brought about neighbourhood renewal in East Manchester and, moreover, has given residents a lasting 'psychological boost', helping thousands to regain pride in the area in which they live..$^{[4]}$

After the reported success of the Commonwealth Games, sports events are increasingly seen as part of a broader tourism strategy and to city planners, major events, if successful, have the ability to project a new image or identity for a city (Gratton et al. 2005). Legacy is commonly associated with a wide range of outcomes, from the physical elements including sporting infrastructure and urban or environmental development through to wider socio-economic improvements such as enhancing skills and workforce development, community relations 

become a motif which is repeated over and over again in the rhetoric surrounding these events. This is evident, for example, in the London 2012 Olympic Games rhetoric, which promised that 'positive repercussions from hosting the greatest show on earth will be felt across the UK's capital for generations to come'.[5] such events are always highly speculative as they lack hard evidence. Critical urban scholars are highly sceptical about the economic impact of show case events, like the Games. They argue that entrepreneurial modes of regeneration, like those seen in East Manchester, have had no economic benefit for local residents (Cook \& Ward 2011; Mace et al. 2007; Mellor 2002; Peck \& Ward 2002; Ward 2003). The social impacts of the Games divide opinion even further. For example, according to Smith and Fox (2007) the Commonwealth Games provided a uniting theme for regeneration to take place and the Legacy Programme paid admirable attention to 'soft' regeneration alongside the physical redevelopment of East Manchester. The authors write that New East Manchester promoted a 'considered approach' to the 'needy beneficiaries' but could have gone further in their efforts to involve local communities in the planning and implementation of some programmes (2007:1140). In contrast, Mellor (2002) argues that the interests of local populations were totally ignored in the regeneration plans. This is because Manchester's post-industrial regeneration has been based on the expectation that the middle classes work and spend their leisure time in the city centre and some of the benefits will 'trickle down to local residents in the form of burger-flipping and cocktail-shaking jobs' (Mellor 2002 in Peck \& Ward 2002:12). In this view, regeneration provides a particular method of inclusion as upgrading the look of the city means reinvestment from the public sector and changing its clientele. Mellor therefore argues that entrepreneurial forms of redevelopment have had disastrous effects on local residents in Manchester where the 'institutional foci of local' life has been obliterated in regenerated areas (2002:232).

Drawing on ethnographic research carried out in East Manchester, this paper suggests that while critiques of entrepreneurialism such as Mellor's (2002), offer important insights into the uneven economic effects of redevelopment, they are insufficient as they do not give voice to the opinions of local residents or shed light on the ways in which social changes are experienced by local populations. They rely on assumptions about the social lives of people living in East Manchester and even though they endeavour to champion the views of residents, the local population is rendered passive in such accounts. As a result, the ways in which local people experience social and urban change and make relationships to place are commonly erased in dominant narratives about the legacies of major sporting events. In order to address this gap in the literature, this paper uses ethnographic research conducted in the residential neighbourhoods in East Manchester to explore the legacy of the Commonwealth Games for local residents. The discussion suggests that ethnography enables us to understand the lived responses, tensions and difficulties that arise in projects of urban transformation which are missing in current accounts and are rather more complicated than entrepreneurial critiques gives credit for.

\section{Methodology}

The discussion draws on ethnographic research from a community study conducted in 2010 which was carried out in Beswick and Openshaw, neighborhoods which lie in close proximity to the main sporting infrastructure which was built for the Games and beyond. The aim of this research was to explore how residents make relationships to place and one another, amid a context of radical urban change. For the period of fieldwork, I chose to live in Beswick, in East Manchester, so I could attempt to become immersed in the local area of my informants. I hoped to gain a deeper understanding of these localities by participating in the local social worlds of my informants (Hammersley \& Atkinson 1983:16). Unlike other qualitative research methods, an ethnographic approach does not have a fixed form (Stewart 1998). During the twelve month period of fieldwork I developed a network of key informants in local sites throughout East Manchester which included the market, coffee mornings, allotments, a number of cafés, local shops, community centres, the Sure Start centre, Mother's Union meetings and, after some time, in informal settings such as people's homes and gardens. My aim was to observe 'incidental moments' of day-to-day life, which are not often captured in other types of research (Becker 1996). This paper reflects on a number of different discussions which took place in these informal settings.

\section{Situating the research: East Manchester}

In order to explain why East Manchester became a site of intense urban redevelopment it is necessary to start by providing a brief historical discussion of deindustrialisation in this locality. In the nineteenth century, Manchester was a leading force in the Industrial Revolution due to the abundance of cotton mills and manufacturing activity. The close proximity and dominance of these sites resulted in the area being dubbed the 'metal bashing heart of the city' (Robson 2002:40). But as Britain moved away from industrial production to the creation of service economies, former industrial neighbourhoods suffered due to dramatic economic decline. Manufacturing jobs were outsourced to other countries taking advantage of cheaper labour. This process, of deindustrialisation, was partly an outcome of globalisation and had dramatic consequences in East Manchester. The second half of the twentieth century saw fundamental shifts in employment and a huge loss of jobs in the city (Mace et al. 2007).

From the late 1960s, the closure of heavy industrial plants caused the landscape in East Manchester to 'shrink' and become 'perforated' (Mace et al. 2007:52). Major firms closed down in quick succession. To name a few: Bradford Colliery (1968), the locomotive manufacturing industry based in Gorton $(1965,1968)$, English Steel (1973), Bradford Glassworks and Stuart Street Power Station (1975) (Tye \& Williams 1994:45). The closure of these plants brought about huge unemployment, depopulation and also resulted in two hundred and fifty hectares of vacant, derelict industrial land. Unemployment 'blackspots' were heavily concentrated in the east of the city due to the position of the industrial sites (Peck \& Emmerich 1993).

In response to widespread unemployment, the decline in population and the onset of entrenched deprivation around Manchester, city council planners introduced a number of different urban renewal projects. In the late 1980s, the redevelopment of the eastern neighbourhoods of the city was scheduled to coincide with the rebuilding of the city centre. It was decided by the Central Manchester Development Cooperation to establish Trafford Park on the west side of the city first (Ward 2003). During this period, the Council allocated funding to the residential areas of Hulme and Moss Side. While other parts of Manchester took precedence for funding, the large geographical area to the east of the city continued to decline. The East Manchester Initiative was formed between 1982 and 1989. Its central aim was to bring private investment and jobs back in to the area (Tye \& Williams 1994). The Initiative was awarded £9 million by the government, which was used mainly for schemes to acquire and demolish derelict buildings and landscape vacant sites in preparation for development.

In 1992, Prime Minister John Major announced that East Manchester would receive £55 million to prepare a bid for the 1996 and 2000 Olympic Games under the East Manchester Regeneration Strategy. In the 1990s, Regional Development Agencies took responsibility for economic regeneration which led to sport being looked on as a catalyst for regional economic development (Gratton et al. 2005).The Olympic bid was a pivotal moment in the regeneration process as it combined plans for new sporting facilities and the regeneration of the surrounding residential neighbourhoods. The Olympics were seen as the 'ultimate expression' of place-marketing which could 'drive change in' and overcome the perceived problems in the area (Cochrane 1996:1330). City planners argued that hosting a major sporting event would help to 'firmly (re)connect Manchester into the globa economy by providing an unprecedented global platform on which to promote a positive image of itself' (Cook \& 
From its inception, the idea to transform East Manchester into a site for a global sporting event prompted debate in the press. How could a space which was associated with dereliction and mass unemployment be reinvented? An article published in the Guardian in 1993, during the bidding process for the 2000 Olympics Games, questioned whether it would be possible for a global sporting event to be hosted in Manchester, a city which was synonymous, in the public imagination with northern industrial, working class life. The journalist, Matthew Engel, discussed the merits of the other countries in competition for the Olympics and asked, 'And will Olympia be builded here among the dark satanic mills?' with the accompanying image (Figure 1).

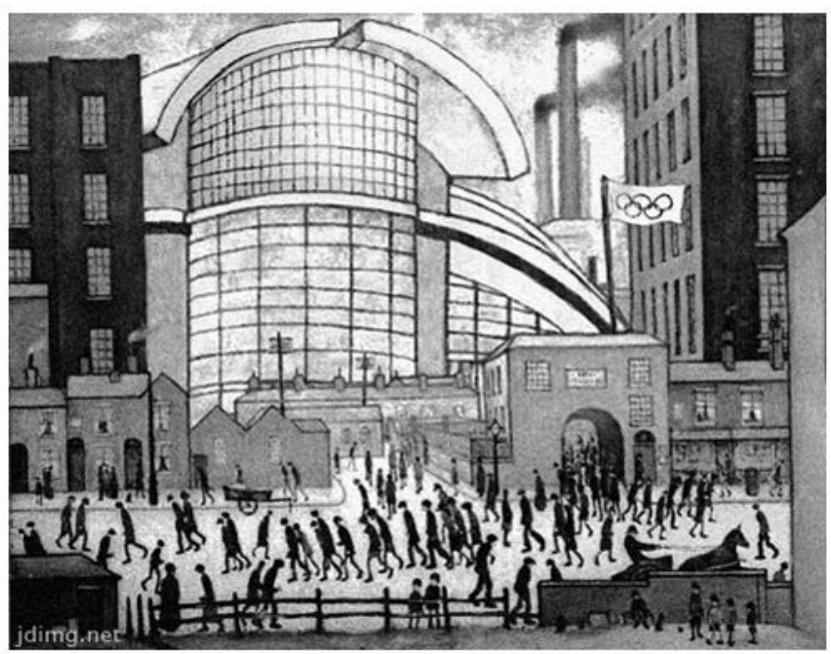

Figure 1. Image from the Guardian Newspaper[6]

The illustration is based on L.S. Lowry's 1930 painting Coming From the Mill. In the place of a manufacturing plant, a stadium has been inserted into the background of Lowry's depiction of industrial life. Lines of unidentifiable workers wander past, with their heads bent low, while chimneys belch out polluted air. The image provocatively questioned whether the Olympics would really bring about any change in Manchester, or whether new sporting infrastructure would simply be ignored: a point to which I later return.

ven though the Olympic bid failed, Manchester managed to secure the Commonwealth Games which took place in 2002. The bidding process was highly significant as new political forms of private and public partnerships were developed. Bidding for the Games transformed the city's 'modus operandi' with the public sector becoming entrepreneurial and the private sector becoming more involved (Cook \& Ward 2011). Prestige was brought to Manchester from participating in the competition for the event (Cochrane 1996). The City Council 'proselytised' the image of the city in order to attract investment and encourage development (Robson 2002). The Games were symptomatic of the intensification of interurban competition whereby cities aggressively compete with one another to increase inward investment (Cook \& Ward 2011). Manchester had by far the largest investment related to hosting a specific sports event ever to be undertaken in Britain and it was the first time that an ambitious legacy programme was designed around a major event (Gratton et al. 2005).

Even though there was public scepticism before the Commonwealth Games, city leaders such as Sir Richard Leese quoted earlier, claimed that Manchester harnessed the enthusiasm and energy of the city to rejuvenate the spirit of the region as well as its urban infrastructure (Brown et al. 2004b). The lynchpin of the Sportcity development in Beswick is the City of Manchester Stadium, otherwise known as 'Eastlands', built on the site of Johnson's Wire Works which closed in 1969. Deindustrialisation had left the landscape in East Manchester 'shrunk and perforated' and so filling empty and derelict areas with 'land hungry users,' such as stadia, was seen as an appropriate solution for the area (Mace et al. 2007:52). A total sum of $£ 170 \mathrm{~m}$ of capital investment was made in Manchester which included $£ 111 \mathrm{~m}$ for the City of Manchester Stadium and $£ 470,000$ on expenditure on other non-sport infrastructure around Sportcity (Gratton et al. 2005).

Local responses to the Commonwealth Games

During the period of fieldwork I conducted in 2010, the Commonwealth Games were often spoken about as a definitive moment in the history of the area by the long-standing residents of East Manchester. At a community centre in Beswick I met Andrew, a resident and community worker in his forties. ${ }^{[7]}$ He moved to Openshaw twenty-five years ago and had become involved in a variety of community groups and residents' associations. At the time of the games he volunteered at some of the sporting events and explained how overall, it was an extraordinary period of time for residents of East Manchester compared to earlier periods of redevelopment:

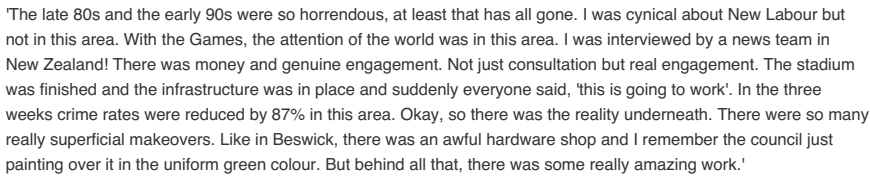

3.11 Even though some of the changes which were made in Beswick were thought to be token and cosmetic like the green paint, Andrew was largely positive. He described how the new facilities were responded to with great excitement and how mass public attention made people feel proud to be from East Manchester. What defined this period, according to Andrew, was that local people were genuinely engaged.

As our conversation progressed, Andrew went on to explain how he moved to Beswick in order to set up a Christian charity in the community after working abroad for a number of years. He told me how the resources which New Labour invested in East Manchester made a terrific difference, but explained how there are still deepseated social problems. In Andrew's opinion, the council missed opportunities to engage people in the years which followed the games.

II think the best way to describe the area is that it was psychologically depressed and in many ways, it still is. I worked in Central America, in areas where there have been civil wars and I don't think they were as depressed. People were angry there but here, they weren't even angry, they didn't question why things were so bad. They had been treated like factory fodder. Vast, vast areas of Manchester were the same. People were cheaper than machines 
Although Andrew was largely positive about the redevelopment efforts which had been introduced to the locality, he felt that in recent years, regeneration had been 'done' to local residents. Similar opinions were voiced by other local residents. As I spent more time in East Manchester I began to realise that dramatic changes brought about by the numerous waves of regeneration in this locality have resulted, for some residents, in a deep sense of confusion about the future. The repeated attempts to redevelop these neighbourhoods have resulted in contestation around place naming and the identities of Beswick and Openshaw.

\section{Creating 'New East Manchester'}

In 2000, the East Manchester Urban Regeneration Company was established and later renamed 'New East Manchester Limited'. It was one of twelve urban regeneration companies in the UK and emerged from the ideological space of New Labour's third way. Under the banner of 'New East Manchester', the area was radically transformed through multiple processes of rebranding and rebuilding. It was one of three Urban Regeneration Companies created by the government to deliver physical improvements to the built environment through partnership with existing agencies (Parkinson et al. 2006). East Manchester became one of the largest sites of urban regeneration in Britain. The Regeneration Framework in 2000 outlined a number of key aims, which included increasing the population of the area by 30,000 , building 12,500 new homes and improving 7000 existing properties (Parkinson et al. 2006). It covers 1900 hectares of land and spreads from the edge of the city centre, along three arterial roads, to Tameside and the M60 orbital motorway (Mace et al. 2007). The name of the company was chosen in order to mark a new period of regeneration which would be distinct from previous state interventions (Ward 2003). The light blue colour on the map in Figure2 shows the localities which were included. The blue circle above Beswick indicates the position of the City of Manchester stadium:

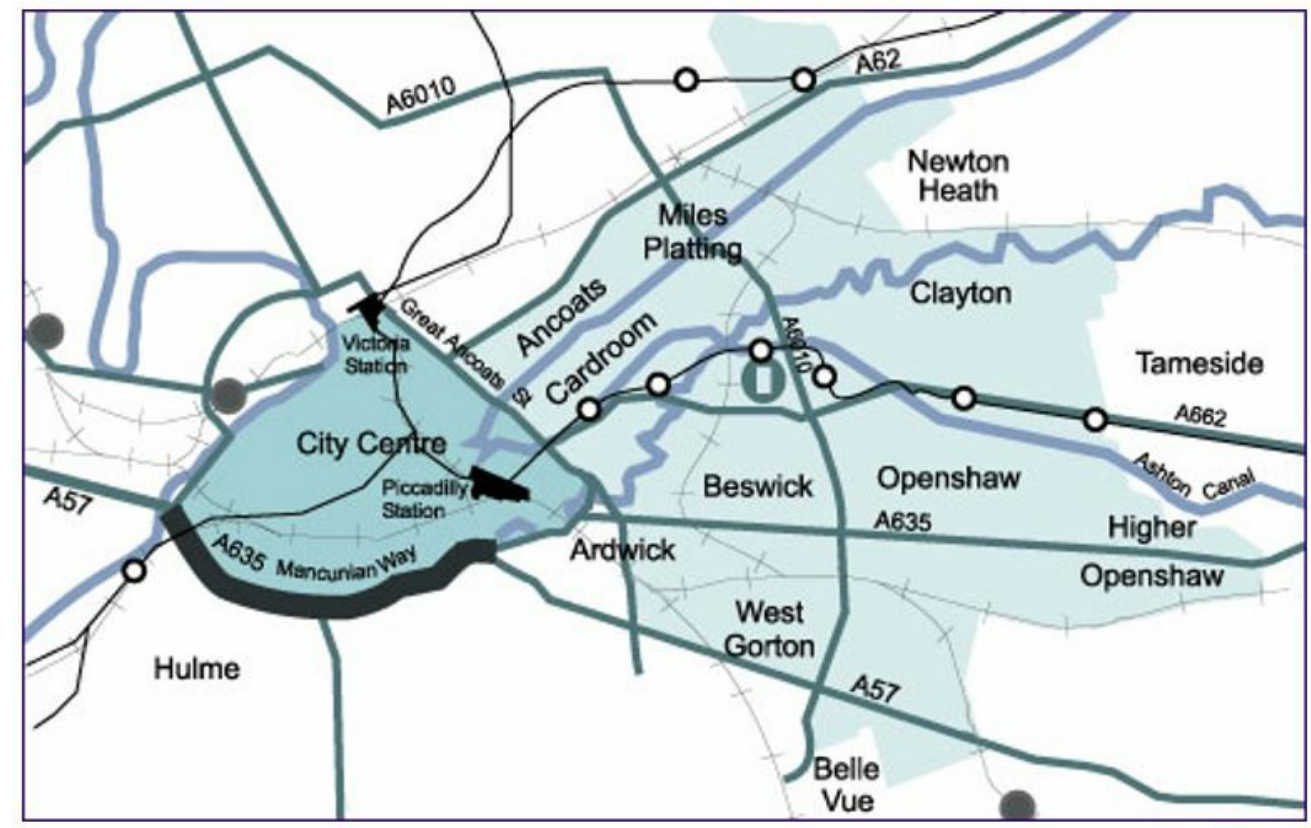

Figure 2. Map of New East Manchester $[8]$

Contestation around place

Throughout the twelve-month period of fieldwork I lived and conducted research in Beswick, I was often confused by the diverse number of names which local people ascribed to different geographical spaces. I was aware that a number of different neighbourhoods had been brought under the banner of 'East Manchester' in the various waves of regeneration. Even so I was still taken aback by how difficult it was to reach any sort of consensus among local people about where the lines of smaller residential areas, such as Beswick, Bradford, Openshaw, Higher Openshaw, Lower Openshaw, Clayton, Newton Heath and Abbey Hey lie. I was not even able to reach a decision about what name I should use for the area where I was living on a so-called mixed estate in Beswick. Eileen, a woman in her sixties, who lived near the City of Manchester Stadium, told me:

'In my day we all called it Bradford and then it changed to Beswick and now they've renamed it Eastlands. Anyone who's from round here will call it Beswick.' had moved to Beswick. He asked me, 'Why don't you call it Bradford?' and explained:

\section{'They used to call the higher bit Bradford, down to where the garage is. Now there isn't even a Lower Openshaw or a Higher Openshaw as it was when we were young. They have redeveloped and changed the names. It's so it's easier to sell houses.'}

To make matters even more confusing, one of my neighbours, Anne, insisted that the housing

development where we both lived was different to the rest of the area and should be referred to as 'New Beswick'. These conversations illustrate how the boundaries and definitions of community have been redrawn in the process of extensive urban regeneration (Brown et al. 2004a).

Place names are powerful tools within regeneration strategies, as they create a vision of a 'new' area. There has been 'frenzied activity' in place marketing in Manchester, which has attempted to overcome negative images of deprivation and the industrial past (Quilley 2000:196). Regeneration programmes are as concerned with creating new discourses and meanings of place as they are with changing their physical form (Raco 2003). However, place names hold great value and a variety of different meanings for local residents. As a result, there is considerable confusion and contestation about the identity of localities in East Manchester. Local residents' question who the new localities have been designed for and what affect future redevelopment will have on local populations. This is particularly evident in discussions around the City of Manchester Stadium, as the following examples reflect. 
MCFC which included a quota for 'community use' of the stadium (Brown et al.2004b). Football clubs in Britain have increasingly been seen to have 'social' and 'community functions' (Mellor 2008). They are perceived to be institutions which have the potential to activate communities and have been incorporated into community and regeneration activities. However, as Mellor describes, football clubs occupy an ambiguous position:

On the one hand, they are economically liberal organisations which pursue profits sometimes at the expense of the public good'. On the other hand, they have social responsibility sections which are designed to address the concerns of civil society (2008:322).

In East Manchester, local residents are confused about the role of MCFC in the regeneration of the locality. I heard many contradictory views about the role of the football club in the future of the area.

4.7 One of my neighbours, Graham, decided to move to Beswick from the south of England. He is a passionate Manchester City supporter and bought a new house which has views of the stadium from his bedroom window. His back garden was adorned with blue and white football flags. Graham holds a season ticket at the stadium and already had lots of friends when he moved to Beswick as he had been going to watch the games for many years. Moving close to the stadium, he told me, was the best decision he has made in his life. For supporters of Manchester United, however, the stadium was often talked about with disdain. Colin, a staunch United fan, joked that every time he drives through Beswick in the fruit and vegetable van, he winds down his window and spits at the stadium. He detests City playing in East Manchester which he said is a United or 'red' area. Colin told me that City has no right playing in Beswick, as United originated in Newton Heath and started to play in Clayton Heath, which lies one mile to the north of Beswick. Since City used to play at Maine Road in Moss Side, a neighbourhood in southern Manchester, United supporters contest that 'blue' fans are not from East Manchester. Unsurprisingly, given the animosity between the teams, City fans maintain that Beswick is now their home and taunt United fans saying that they are not real 'Mancunians' as their stadium is in Old Trafford which lies in a neighbouring council ward. These types of contestation and joking are not surprising or unique to East Manchester but what is interesting is the way in which the role of the football club is used in different ways to question what impact they will have for local people.

Local residents often teased one another about affiliations to particular football teams among family members. I met Paul and Kim, a couple in their sixties at Openshaw Allotments. When I joined them at their plot they would often bicker about their opposing teams. Paul supports United and enjoyed teasing his wife by criticising the stadium in Beswick.

'I don't like the stadium. It looks like a council car park. There is no character to it. At least Maine Road [the old stadium in Moss Side] had some character to it. I think it's too bland.'

Even though Paul did not like the appearance of the stadium he told me that the owners, 'the Arabs', a multi-millionaire family who have bought MCFC would bring good fortune to East Manchester.[10] Paul explained how the owners of the football club have unlimited wealth and told me that he was certain they would invest money locally. MCFC use the stadium under an agreement with the council. However, Paul was under the impression that the football club owns the stadium and has complete control over it. Even though he did not like City playing in Beswick he thought that overall the club would have a good influence in East Manchester.

4.10 Feelings of uncertainty about the future dominated local discussions in East Manchester. Kathleen, a woman in her late fifties, told me that she had heard a rumour that the estate where she lives in Beswick had been earmarked for development. She heard that the houses would be demolished as the land was going to be sold to the owners of the stadium as they wanted to acquire more land to build a new MCFC leisure park. Kathleen was very concerned about these stories and explained that they were 'more than a rumour'. She suspected that the club was hoping to expand so they could bid to host the World Cup in England in 2018 and was anxious about what would happen to her house and the others on her estate. Kathleen had invested a great deal of effort on her home and enjoyed living in Beswick where she was close to her family. A couple of days after our initial conversation, I ran into a woman who worked for New East Manchester regeneration team at a local event. With Kathleen's permission I asked the employee whether or not the plans for the new MCFC development were true. She told me, flatly, that the houses would not be demolished as the club had not obtained permission to buy the land. I relayed the news to Kathleen but it did not allay her fears. She said that rumours were widespread and explained how she could not rest easy as the regeneration agency had lied before'. The stories amounted to more than a rumour for her because of the severity of what could happen.

4.11 My findings reveal a strong narrative of uncertainty among residents living in East Manchester who felt vulnerable in the face of the power of the football club. Some local people were concerned about what effect the football club's rising popularity, success and wealth would mean for the future of East Manchester. There were many rumours which circulated about plans to build a leisure park, more training facilities and accommodation next to the stadium and residents were concerned about Sheikh Mansour's investment in MCFC. At the same time, other residents were excited about the potential for further redevelopments and businesses being set up in Beswick. As well as joking about football affiliation and contestation around which team was truly 'Mancunian' and more authentic than the other, the stadium is a fundamental symbol of change in East Manchester.

4.12 The entrepreneurial critiques of regeneration which are discussed above resonate with my research findings as they raise important questions about the economic and social impact of the Games. However, the local responses to the Commonwealth Games and the subsequent regeneration which has taken place are rather more complex than the critical accounts of entrepreneurial modes of redevelopment give credit for. For example, Mace et al. (2007) suggest that the sporting infrastructure in East Manchester has been 'parachuted' into the locality with no evidence that it has encouraged social inclusion. However, my findings do not support this analysis. It was clear from the discussions I had with local residents that the sporting infrastructure has resulted in various social implications. For some residents, like Graham, a staunch MCFC fan was attracted to the area due to his social network of supporters. While for others like Kathleen they felt that the interests of football fans visiting East Manchester have been given precedence over the disruption to the lives of local people.

4.13 I argue that while it is important to draw attention to the uneven economic effects of redevelopment, these critiques must be extended so they take account of the multiple contingent perspectives of local residents. For example, Ward (2003) describes how East Manchester is one of the most 'policy thick' regions in Britain due to the complex configuration of initiatives which has emerged. He argues that the area has become a rather 'unreal place' and says that Beswick resembles the imaginations of local and regional policies, rather than those of the community (2003:124). The discussions I had with local people do not support his argument. Multiple place names are ascribed to different geographical areas in the locality by local residents and a deep sense of confusion about the future is evident but I found nothing to suggest that the newly regenerated landscape was seen to be 'unreal' compared to the past. In fact, some residents, like Andrew, were hopeful for further state intervention to take place in the area and others, like Paul were very excited about the potential role the football club might play in the future of the area.

4.14 Instructive here is geographer Massey's $(1995,2001)$ nuanced approach to place. She suggests that places are always constructed out of articulations of social relations and always informed by politics. Massey's approach helps explain why ambiguity and contradiction surround key developments in East Manchester such as the stadium in Beswick. While many local residents were proud that the locality now attracts many sports fans for 
matches, they also felt that the interests of football fans were being put before those of local people. Further, even though there was general support for MCFC investing in East Manchester, there was also concern. Many informants felt that the club could play a positive role in the area by encouraging economic investment and bringing visitors to the area, while others were anxious that the interests of local people were being ignored. The variety of opinions reflect how understandings of the 'public' are 'multiple and differentiated' and have different demands on localities (Massey 2001:467).

As Raco and Tunney (2010) argue, value should be given to the diversity of economic and social activities and the strengths of urban change, as opposed to crude dichotomies between regenerated and lifeless urban spaces. Urban development radically restructures the quotidian, day to day lives of individuals, businesses and communities but in ways that are hidden from view (Raco \& Tunney 2010). The residents who I worked with in East Manchester in 2010 suggested that the identity of the regenerated landscape is contentious and open to interpretation. Even though there is overwhelming support for the regeneration activities taking place in the locality, many long-standing residents are anxious and uncertain about the future. This is not because residents are against change but because as Massey (2001) suggests, places are 'part of who you are' which means that transformations of the landscape have deeply personal implications.

\section{Conclusion}

5.1 To return to the Lowry-esque image which I referred to in this paper (Figure. 1), my ethnographic research indicates that in contrast to the scene depicted in the illustration, the stadium and other sporting infrastructure has not simply been dropped into the existing social milieu of East Manchester. The facilities built for the Commonwealth Games in 2002 have not only reshaped the built environment but were accompanied by a huge number of funding initiatives and schemes as part of East Manchester's social regeneration. Rather than one moment of transformation, the social life and landscape in the area has been reconfigured in multiple ways through a series of different and often truncated stages of redevelopment. Since local people report constant changes to neighbourhoods it is very difficult to talk about how a single event has changed people's experiences in a uniform way. These observations reveal how the Games have had a range of long-term impacts for residents living across these localities.

Ethnographic research reveals how a range of actors operate in different worlds in a shared space. The 'community' and 'regeneration' are not in opposition to each other as the entrepreneurial critiques would suggest (Mellor 2002; Ward 2003). Instead, local residents construct multiple ideas about belonging to the new landscape and therefore hold different relationships to place. As the examples in the paper reflect, the way in which my informants construct ideas about place is shaped by historical ideas about East Manchester. Since places are 'part of who you are', there are many different ways of constructing the relation between personal and place identity (Massey 2001). My research shows that despite the promises of legacy, the future continues to be defined by uncertainty for many residents. These ethnographic findings are rather more complicated than dominant narratives would suggest. For example, in dominant regeneration rhetoric, legacy is regarded as solely positive (Matheson 2010) whereas critical accounts point to the failure of legacy projects for marginalised populations living within them (Cook \& Ward 2011; Mace et al. 2007; Mellor 2002; Peck \& Ward 2002; Ward 2003). I argue that while the critical accounts reveal important lessons about the unequal effects of redevelopment, they must be extended so they can take account of the long term lived responses to change and the enduring sense of uncertainty which is evident for many residents. These observations support Raco and Tunney's (2010) call for greater awareness of the plurality of activities and socioeconomic practices that create vibrant and functioning cities. Ethnographic insights into the social life of localities which are implicated in major sporting events provide a nuanced understanding of the lived effects of urban change and shed light on the myriad, ambiguous and contingent social effects of urban change. They fill in significant gaps in the literature which either celebrate the short-term impact of the Games, or critique the entrepreneurial redevelopment which has taken place.

\section{Notes}

ECOTEC An Evaluation of the Commonwealth Games Legacy Programme. 31-32 Park Row.Leeds LS1 5JD. (page 1).

- New East Manchester Annual Report and Accounts (2002-2003) 'The New Town in the City'. From http://www.google.co.uk/url?

sa=t\&rct=j\&q=\&esrc=s\&source=web\&cd=1\&ved=0CCIQFjAA\&url=http\%3A\%2F\%2Fwww.manchester.gov.uk\%2Fdownload\%2Fdownloads\%2Fid\%2F16307\%2Fnew_east_manchester_annual_rep

McKeegan, Alice. "Legacy of Commonwealth Games Lives on in Manchester."Manchester Evening News, July 15th 2014.

"Sir Richard Leese: Manchester Should Be Proud of Our Commonwealth Games." Manchester Evening News, July 16 th 2012.

From http://www.olympic.org/content/olympism-in-action/olympic-legacy/london-2012-legacy/.

Engel, Matthew (1993) 'And will Olympia be builded here among the dark satanic mills?' Guardian (June 4th). Permission to use image from Jac Depczyk http://www.jacdepczyk.com.

All names have been changed to protect the identity of my informants

From http://www.neweastmanchester.com permission granted to use image.

After the period of fieldwork, the stadium was renamed the Etihad Stadium in July 2011, after sponsors of the club Etihad Airways.

Sheikh Mansour, a member of the Abu Dhabi's ruling Al Nahyan family bought MCFC for £210m in 2008

\section{References}

BECKER, H (1996) The Epistemology of Qualitative Research. In Jessor R, Colby, A and Shweder, R (Eds.) Ethnography and Human Development, Chicago: The University of Chicago Press.

BROWN, A, Mellor G, Blackshaw T, Crabbe T and Stone C (2004a) "Football and Its Communities "Report 2 for the Football Foundation. 
BROWN, A, Mellor G ,Blackshaw T, Crabbe T and Stone C (2004b) "The Impacts of a Stadium Move on the Communities of a Football Club: The Example of Manchester City FC." Football and its Communities: Report 3 for the Football Foundation.

COCHRANE, A (1996) "Manchester Plays Games: Exploring the Local Politics of Globalisation."Urban Studies Vol. 33, Issue 8.

COOK, I \& Ward K (2011) "Trans-Urban Networks of Learning, Mega Events and Policy Tourism: The Case of Manchester's Commonwealth and Olympic Games Projects." Urban Studies Vol. 48, Issue 5.

DAVIES, L. (2012) "Beyond the Games: regeneration legacies and London 2012".Leisure Studies, Vol. 31, Issue

GRATTON, C, Shibli S and Coleman R (2005) "Sport and Economic Regeneration in Cities.'Urban Studies 42, no. 5/6 (2005): p. 985- 99

HAMMERSLEY, M AND Atkinson, P. (1983)Ethnography: Principles and Practice. Tavistock Publications

HARVEY, D (1989) "From Managerialism to Entrepreneurialism: The Transformation in Urban Governance in Late Capitalism ". Geografiska Annaler Vol.71B, Issue, 1 p. 3-17.

MACE, P, Hall P and Gallent N (2007) "New East Manchester: Urban Renaissance or Urban Opportunism?" European Planning Studies Vol. 15, Issue 1.

MACLEOD, G \& Ward K (2002) "Spaces of Utopia and Dystopia: Landscaping the Contemporary City." Geografiska Annaler. Series B, Human Geography Vol. 84, Issue 3/4.

MACRURY, I (2008)"Re-Thinking the Legacy 2012: The Olympics as Commodity and Gift."Twenty-First Century Society Vol.3, Issue 3.

MASSEY, D (1995)"Places and Their Pasts." History Workshop JournalVol.39, Issue 1.

MASSEY, D (2001)"Living in Wythenshawe." In I Borden, Kerr J, Rendell J and Pivaro A (Eds.)The Unknown City: Contesting Architecture and Social Space Cambridge, Massachusetts London, MIT Press.

MATHESON C (2010) "Legacy Planning, Regeneration and Events: The Glasgow 2014 Commonwealth Games." Local Economy Vol.25, Issue 1.

MELLOR, G (2008) "'The Janus-Faced Sport': English Football, Community and the Legacy of the 'Third Way' ". Soccer and Society Vol.9, Issue 3.

MELLOR, R (2002)"Hypocritical City: Cycles of Urban Exclusion." In Peck, J and Ward, K.City of Revolution: Restructuring Manchester. Manchester: Manchester University Press.

PARKINSON, M, Evans R, Meegan R,Karecha, J and Hutchins M (2006) "Interim Evaluation of New East Manchester." Liverpool: European Institute for Urban Affairs, Liverpool John Moores University.

PECK, J \& Emmerich M (1993) "Manufacturing Manchester? Industrial and Labour Market Restructuring in Greater Manchester." Manchester International Centre for Labour Studies, no. Working Paper 4.

PECK, J \& Ward K (2002) City of Revolution: Restructuring Manchester. Manchester: Manchester University Press.

QUILLEY S (2000) "Manchester First: From Municipal Socialism to the Entrepreneurial City ". International Journal of Urban and Regional Research Vol. 24, Issue 3.

RACO, M (2003) "Remaking Place and Securitising Space: Urban Regeneration and the Strategies, Tactics and Practices of Policing in the UK." Urban Studies Vol. 40, Issue 9.

RACO M \& Tunney E (2010) "Visibilities and Invisibilities in Urban Development: Small Business Communities and the London Olympics 2012." Urban Studies Vol.47, Issue 10.

ROBSON B (2002) "Mancunian Ways: The Politics of Regeneration." In Peck J and Ward K (Eds) City of Revolution: Restructuring Manchester. Manchester: Manchester University Press.

SMITH A and Fox T (2007) "From 'Event-Led' to 'Event-Themed' Regeneration: The 2002 Commonwealth Games Legacy Programme." Urban Studies Vol.44, Issue 4/5.

STEWART A (1998) The Ethnographer's Method. London: Sage.

TYE R and Williams G (1994) "Urban Regeneration and Central-Local Government Relations: The Case of East Manchester." Progress in Planning Vol. 42, Issue 1.

WARD K (2003) "Entrepreneurial Urbanism, State Restructuring and Civilizing 'New' East Manchester "Area Vol. 35 , Issue 2 